\section{Risiko for cerebral parese påvirkes av fødselstidspunkt}

\author{
Risikoen for cerebral parese er lavest hos barn født i uke 40, mens \\ risikoen øker med både avtakende og økende svangerskapsalder. \\ Det viser en ny norsk studie publisert i JAMA.
}

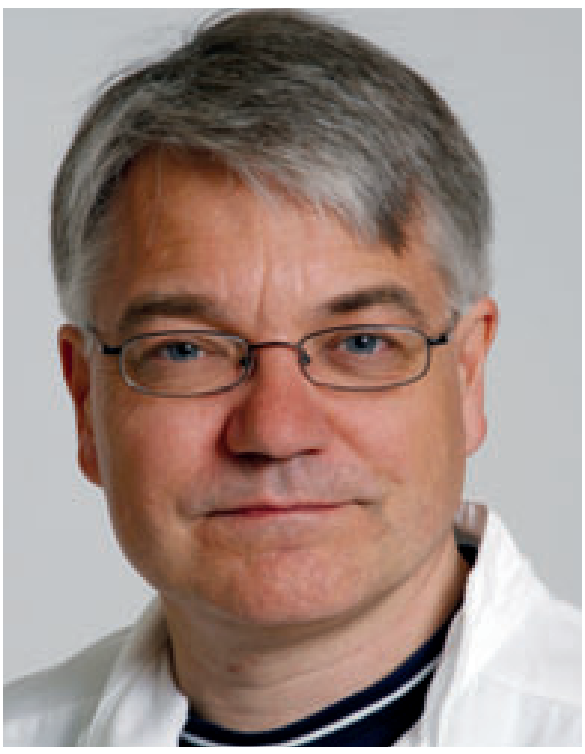

Dag Moster, studiens førsteforfatter. Foto Leif-Arne Markussen, Universitetet i Bergen

Cerebral parese er den vanligste årsaken til fysisk funksjonshemning i barnealder og rammer ca. to av 1000 barn. Prematur fødsel øker risikoen for cerebral parese, men de fleste barn med cerebral parese er ikke født prematurt. Det finnes lite kunnskap om mulig sammenheng mellom cerebral parese og svangerskapsalder for barn født til og etter termin, men nå har norske forskere undersøkt dette (1).

- Ved hjelp av Medisinsk fødselsregister identifiserte vi alle barn i perioden $1967-$ 2001 som var født til termin samt alle født etter termin. Vi ekskluderte flerlinger og barn med medfødte misdannelser. Studiekohorten på 1,68 millioner barn ble fulgt til utgangen av 2005. Opplysninger om død ble innhentet fra Dødsårsaksregisteret og opplysninger om cerebral parese fra NAVs registre, sier studiens førsteforfatter Dag Moster ved Haukeland universitetssykehus og Universitetet i Bergen.

- Flest barn blir født i uke 40 og risikoen for cerebral parese var lavest $\mathrm{i}$ denne perioden $(0,99$ per 1000$)$. Risikoen økte så med både avtakende og økende svangerskapsalder. Ved 38 uker var risikoen økt med $30 \%$ og ved 37 uker med $90 \%$. Tilsvarende økte risikoen med $40 \%$ når barnet ble født etter 41 uker. Forskjellene var enda større i en sub- kohort der terminbestemmelse var basert på ultralyd og ikke menstruasjonsdata.

Den biologiske forklaringen på den U-formede assosiasjonen mellom svangerskapsalder ved fødsel og cerebral parese er ukjent. Det kan tenkes at fødsel ved 40 uker er det mest optimale for barn og at fødsel i økende avstand fra 40 uker gjør den nyfødte hjerne mer sårbar. En alternativ forklaring er at barn som allerede i fosterlivet har en predisposisjon for å utvikle cerebral parese, også har en forstyrrelse i reguleringen av fødselstidspunktet.

Vi viser også at barn med medfødte misdannelser har en tilsvarende U-formet assosiasjon med svangerskapsalder, noe som kan gi støtte til den siste forklaringsmodellen. Inntil de biologiske årsaksfaktorene er bedre kartlagt, bør man være varsom med å bruke studien som argument for intervensjon av forløsningstidspunkt, sier Moster, som har skrevet artikkelen sammen med Allen Wilcox, Stein Emil Vollset, Trond Markestad og Rolv Terje Lie.

\section{Samarbeid mellom Bergen og USA}

Studien er et resultat av et produktivt samarbeid mellom det registerepidemiologiske miljøet ved Universitetet i Bergen, Barneklinikken, Haukeland universitetssykehus og National Institutes of Health, USA. Studiens førsteforfatter, Dag Moster, har det siste året vært gjesteforsker ved National Institute of Environmental Health Sciences, National Institutes of Health, i samarbeid med studiens andreforfatter professor Allen Wilcox. Miljøet i Bergen har utmerket seg flere ganger med publikasjoner i høyt rangerte tidsskrifter. Moster, Lie og Markestad publiserte i 2008 en artikkel i New England Journal of Medicine om langtidsresultater av prematur fødsel (2).

\section{Erlend Hem}

erlend.hem@medisin.uio.no

Tidsskriftet

\section{Litteratur}

1. Moster D, Wilcox AJ, Vollset SE et al. Cerebral palsy among term and postterm births. JAMA 2010; 304: 976-82.

2. Hem E. Premature har økt risiko for funksjonshemninger. Tidsskr Nor Legeforen 2008; 128 1799.

\section{Ordforklaringer}

Cerebral parese er en samlebetegnelse på en rekke ikke-progredierende tilstander som kjennetegnes av endret bevegelse og/eller stilling, antatt forårsaket av en skade i den umodne hjerne. De motoriske vansker kan også være ledsaget av andre nevrologiske funksjonsforstyrrelser.

Fødsel til termin: Uke 37-41 i svangerskapet

Prematur fødsel: Før uke 37 i svangerskapet

Fødsel etter termin: Fra uke 42 i svangerskapet

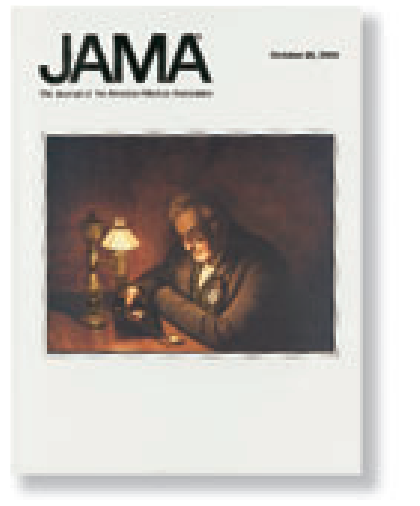

Artikkelen ble publisert 1.9. 2010 i JAMA (www.jama.com), som regnes som en av de «fem store» innen medisinsk publisering ved siden av New England Journal of Medicine, BMJ, Annals of Internal Medicine og The Lancet

\section{Tips oss}

Er du i ferd med å publisere eller har du nylig publisert iet internasjonalt tidsskrift? Send tips til erlend.hem@medisin.uio.no 